IZA DP No. 5970

Climbing the Job Ladder:

New Evidence of Gender Inequity

David W. Johnston

Wang-Sheng Lee

September 2011 


\title{
Climbing the Job Ladder: New Evidence of Gender Inequity
}

\author{
David W. Johnston \\ Monash University \\ Wang-Sheng Lee \\ RMIT University \\ and IZA
}

\section{Discussion Paper No. 5970 \\ September 2011}

\author{
IZA \\ P.O. Box 7240 \\ 53072 Bonn \\ Germany \\ Phone: +49-228-3894-0 \\ Fax: +49-228-3894-180 \\ E-mail: iza@iza.org
}

\begin{abstract}
Any opinions expressed here are those of the author(s) and not those of IZA. Research published in this series may include views on policy, but the institute itself takes no institutional policy positions.

The Institute for the Study of Labor (IZA) in Bonn is a local and virtual international research center and a place of communication between science, politics and business. IZA is an independent nonprofit organization supported by Deutsche Post Foundation. The center is associated with the University of Bonn and offers a stimulating research environment through its international network, workshops and conferences, data service, project support, research visits and doctoral program. IZA engages in (i) original and internationally competitive research in all fields of labor economics, (ii) development of policy concepts, and (iii) dissemination of research results and concepts to the interested public.
\end{abstract}

IZA Discussion Papers often represent preliminary work and are circulated to encourage discussion. Citation of such a paper should account for its provisional character. A revised version may be available directly from the author. 
IZA Discussion Paper No. 5970

September 2011

\section{ABSTRACT}

\section{Climbing the Job Ladder: New Evidence of Gender Inequity ${ }^{*}$}

An explanation for the gender wage gap is that women are less able or less willing to 'climb the job ladder.' However, the empirical evidence on gender differences in job mobility has been mixed. Focusing on a subsample of younger, university-educated workers from an Australian longitudinal survey, we find strong evidence that the dynamics of promotions and employer changes worsen women's labour market position.

JEL Classification: J16, J33, J71

Keywords: $\quad$ promotions, job changes, gender, wage gap

Corresponding author:

David W. Johnston

Monash University

Centre for Health Economics

Level 2, Building 75

Clayton, Victoria 3800

Australia

E-mail: david.johnston@monash.edu

\footnotetext{
* This paper uses unit record data from the Household, Income and Labour Dynamics in Australia (HILDA) Survey. The HILDA Project was initiated and is funded by the Australian Government Department of Families, Housing, Community Services and Indigenous Affairs (FaHCSIA) and is managed by the Melbourne Institute of Applied Economic and Social Research (Melbourne Institute). The findings and views reported in this paper, however, are those of the authors and should not be attributed to either FaHCSIA or the Melbourne Institute.
} 


\section{Introduction}

A large empirical literature has established that women receive lower wages than men. The wage gap exists even when comparing men and women with the same education and experience, and when comparing men and women who work in the same industries - for reviews of the literature see Blau and Kahn (2000) and Weichselbaumer and Winter-Ebmer (2005). Recently, a number of studies using cross-sectional data have found that the magnitude of the gender gap varies across the wage distribution, with the gap seemingly largest amongst workers earning relatively high wages in the private sector. This pattern has been found in a number of European countries (Albrecht et al., 2003; Arulampalam et al., 2007), Australia (Kee, 2006; Baron and Cobb-Clark, 2008) and the United States (Le and Miller, 2010). The general conclusion from this literature is that there exists a 'glass ceiling' for women, which prevents women from attaining the more highly paid roles within their work places.

A natural explanation for the glass ceiling phenomenon is that women are less able or less willing to 'climb the job ladder' through promotions and through changing employers. The empirical evidence on gender differences in job mobility has, however, yielded mixed results. Jones and Makepeace (1996), Ransom and Oaxaca (2005), Pekkarinen and Vartianinen (2006), and Blau and DeVaro (2007) find lower promotion rates for women than for men with similar characteristics. In contrast, Hersch and Viscusi (1996), Paulin and Mellor (1996), Barnett et al. (2000), Booth et al. (2003), and Giuliano et al. (2005) find either no gender differences in promotion rates or evidence of a preference towards promoting women. A related explanation for the glass ceiling phenomenon is that wage increases associated with promotions and employer changes are higher for men than for women. Again, the empirical evidence for this explanation is mixed; Hersch and Viscusi (1996) and Booth et al. (2003) find higher wage increases for men, while McCue (1996) and Cobb-Clark (2001) find comparable wage increases or higher wage increases for women.

The mixed findings with regard to gender differences in promotion rates and in the returns to promotions may be due to institutional and cultural differences between countries in which the studies are based. Alternatively, it may be due to the common reliance on data from one or a small number of firms or establishments, meaning that results are not necessarily replicable when using data from other distinct industries. For example, it's likely that some industries actively discriminate against women while others do not. Another possibility is that 
the estimated gender effects are sensitive to the set of control variables included in the regression analysis. For example, a parsimonious specification containing controls for only experience and education may find significant gender differences, whereas a larger specification containing additional controls, such as industry, occupation, birth expectations and personality, may not.

Given the ubiquitous and persistent nature of the gender wage gap, and given the conflicting evidence for some prominent explanations, further work in this area is needed. In this paper, we address the following questions. Is there a gender gap in promotion rates and employer change rates? Are male and female workers rewarded equally from being promoted and from changing employers? And finally, can any gender differences in mobility be explained by gender differences in job preferences? To address these questions we use Australian survey data that is well suited to this investigation. Firstly, the data is longitudinal, meaning we can examine individual-level wage dynamics and also better control for confounding unobservables by estimating fixed-effects regression models. Secondly, the data constitutes a nationally representative sample rather than a sample of workers from a particular firm or industry, meaning our estimates will capture average behaviour across the entire labour market. Thirdly, the data includes detailed information on individuals and jobs, and so it is possible to control for an extensive array of differences between male and female workers. Finally, the data contains direct information on promotions and employer changes for all respondents, which is an improvement on the job mobility information contained in other large longitudinal data sets. For example, McCue (1996) uses data from the Panel Study of Income Dynamics (PSID) and concludes that "there are many inconsistencies in the PSID tenure with employer data, which make it difficult to determine if and when sample members change jobs."

Most closely related to this study is research by Booth et al. (2003). They use British Household Panel Survey (BHPS) data on employees aged less than 60 to estimate probit promotion models and fixed-effects wage models. Their main empirical results are that females and males are equally likely to receive promotions, but that men receive higher wage increases when promoted. Therefore, their conclusion regarding women's relative wage position is that the promotion process "may very well increase the disadvantage, not through a lower promotion probability, but through a lower wage reward over time to promotion." We also estimate probit promotion models (with random-effects in our case) and fixed-effects wage models, but we use different data, focus on a narrower sample of employees, and also examine an expanded set of 
outcomes. For example, we examine gender gaps in employer changes, and the role of job satisfaction and time allocation in explaining the gender gaps. Importantly, our findings which we summarise below are also different from those in Booth et al. (2003).

Another paper related to our research is Manning and Swaffield (2008). The focus of their study is the gender gap in wage growth for recent labour market entrants, which they argue is important to understand because it is a primary driver of the overall gender pay gap. They find that human capital, job-shopping and psychological theories can explain only a minor proportion of the gap in Britain. In descriptive analysis we find that the observed gender gap in Australia is also driven by wage growth disparities for less-experienced workers, and that this is especially true for university educated workers. Consequently, we focus on less-experienced, universityeducated workers for much of our empirical analysis.

Our results contain two main findings: women are much less likely to be promoted than men, and women receive much smaller wage increases when promoted and when changing employers. In fact, women on average are found to receive a wage penalty when changing employers. Furthermore, we find that women are no more satisfied in their current roles than men, women apply and search for new jobs at the same rate as men, and women are not trading away pay for reduced working hours, increased flexibility, or more interesting work. Thus, a commonly presented explanation for gender wage differentials - that women value nonmonetary aspects of work more highly than men - does not appear to explain our results.

Since the paper uses Australian data, Section 2 briefly presents some institutional features of the Australian labour market that are relevant for women's careers and a brief review of research examining the Australian gender wage gap. The data are described and a descriptive analysis of wages and job mobility are presented in Section 3. Section 4 includes estimates of the gender gap in job mobility and estimates of the gender gap in the returns to job mobility. In section 5 we discuss different potential explanations for our empirical results and in section 6 we conclude the paper.

\section{The Australian Gender Wage Gap}

The key principle which formed the basis for female wage determination in Australia in the first half of the 20th century was laid out in the Rural Workers Case of 1912. It stated that where women were of little threat to male employment (i.e. in female dominated jobs), they were to be 
paid between 54 and 66 percent of the male wage rate. In 1969, Equal Pay for Equal Work was introduced, which aimed at addressing the institutional discrimination that had taken place since 1912. Three years later, a modified version of this ruling - referred to as Equal Pay for Work of Equal Value - was introduced to further ensure that work performed by women in female dominated jobs was not under-valued. In 1974, a single minimum wage was introduced, ensuring that men and women in entry level jobs start at the same point. Further legislative changes aimed at narrowing the gender wage gap were introduced in the 1980s and 1990s. The Sex Discrimination Act of 1984 and the Workplace Relations Act of 1996 made it illegal to discriminate against someone on the basis of gender, marital status, and pregnancy or family responsibilities. More recently, the Affirmative Action (Equal Employment Opportunity for Women) Act of 1986 was revised in 1999 to The Equal Opportunity for Women in the Workplace Act of 1999. It requires employers with 100 or more people to establish a workplace program to remove the barriers to women entering and advancing in their organisation.

Despite the legislative developments in the 1970s, 1980s and 1990s, however, female average wages remained significantly less than male average wages. A perennial explanation for this difference is that there exist important human capital differences between genders. Consequently, there have been a number of Australian studies that estimate the size of the Australian gender wage gap controlling for human capital and demographic differences between genders. Most often, the studies used the Blinder-Oaxaca decomposition procedure, in which average wage differences are decomposed into a component reflecting differences in human capital and a component reflecting discrimination. For examples, see the papers by Miller (1994) and Preston and Crockett (1999), and the overview provided in Borland (1999). The general finding in these papers is that gender differences in educational qualifications, experience and demographic characteristics are unimportant in explaining the wage gap. More recently, a number of studies have applied decomposition procedures that generate estimates of the conditional wage gap at different points in the wage distribution. These studies found that the gap is largest amongst workers earning relatively high wages, especially in the private sector. For example, Kee (2006) concludes that "in the private sector, even after controlling for occupation and industry, the gender gap accelerated at the upper tail of the conditional wage distribution, and hence there is a glass ceiling." 
Several studies have also focused on estimating how the Australian gender wage gap has changed over time. In general, there appears to be a well established pattern that is observed - a considerable narrowing of the gender wage gap towards the mid 1970s, slower growth in female relative wages in the 1980s, and then relative stability in the 1990s. Gregory (1999) suggests that the reduction of the gap between the 1960s and 1990s is likely a result of the legislative and institutional developments that took place over this period.

In the 21 st century, Australian women experience an earnings disadvantage that is one of the lowest amongst OECD countries (Eastough and Miller, 2004). The latest Survey of Employee Earnings and Hours available from the Australian Bureau of Statistics (ABS) shows that average weekly total cash earnings of full-time non-managerial adult employees in August 2008 was $\$ 1,280.40$ for men and $\$ 1,062.30$ for women, which is equivalent to a female-male ratio of 83.0 per cent. ${ }^{1}$ This weekly earnings gap is larger than the hourly earnings gap because on average men tend to work more hours than females. For example, the same ABS survey also shows that for this category of employee average weekly total hours was 40.6 hours for men and 38.3 hours for women. However, despite an internationally low gender wage gap, the question remains why the extensive institutional changes that have taken place in Australia have not eliminated the wage gap entirely. The aim of this paper is to shed light on this issue by examining gender differences in job mobility.

\section{Data and Descriptive Analysis}

We investigate the interplay between gender, job mobility and wages with data from waves 2 to 8 of the Household, Income and Labour Dynamics in Australia (HILDA) survey. ${ }^{2}$ HILDA is a household-based longitudinal study that is nationally-representative, with the exception of undersampling individuals living in more remote areas of Australia. It began in 2001 with a survey of 13,969 persons in 7,682 households, and in each year since interviews have been conducted with all willing members of each household who are at least 15 years old at the time of the interview. In the interviews detailed information is collected on labour force dynamics, education, income, family formation, health and other specialised topics.

\footnotetext{
${ }^{1}$ See Australian Bureau of Statistics, Employee Earnings and Hours Australia, Cat no. 6306.0.

${ }^{2}$ Wave 1 of the HILDA survey did not include questions about promotions or job changes.
} 
The HILDA data has certain qualities that make it particularly suitable for an investigation of job mobility. First, and most importantly, job mobility information is collected for all respondents. In particular, respondents are asked whether in the past 12 months they have been "Promoted at work" and whether they have "Changed jobs (i.e. employers)." This information means we do not need to rely on information from job diaries, which can contain non-trivial measurement error. Second, HILDA's longitudinal nature means we can examine individual-level wage dynamics and also better control for confounding unobservables by estimating fixed-effects regression models. Third, HILDA data is a nationally representative sample of Australians rather than a sample of workers from a particular industry or particular firm, meaning our estimates will capture average behaviour across the entire labour market. Fourth, HILDA contains exceptionally detailed information on individual demographic characteristics, allowing us to control for a wide range of potential differences between male and female workers.

Our estimation sample includes respondents that are employees (i.e. not self-employed), observed to work full-time in at least one wave of the panel, not studying full-time, and have non-missing wage, mobility and demographic information. Attention is restricted to persons not studying full-time, even if they are employees, in order to focus on a population that is likely to be fully engaged in the labour market. The full-time employment restriction is imposed in order to eliminate workers with weak attachment to the labour force. For most of the empirical analysis we further restrict the sample to university-educated employees with less than 20 years of experience. $^{3}$ The sample restrictions lead to an unbalanced panel comprising 726 men and 881 women, respectively, with 2605 and 3083 person-year observations.

The relationship between experience and wage growth is plotted in Figure 1 for men and women who are not university-educated, and in Figure 2 for men and women who are universityeducated. ${ }^{4}$ Figure 1 shows that the wage growth rates for non-university-educated men and women - most of whom are high-school dropouts - follow a very similar trajectory. Wage growth is larger for men with less than 15 years experience and larger for women with over 30 years experience, but the gaps are small and insignificantly different from zero. Importantly, the

\footnotetext{
${ }^{3}$ Following Manning and Swaffield (2008) we define experience as age minus years of education. Thus, our experience restriction combined with our education restriction effectively restricts the sample to employees aged 21 to 41 .

${ }^{4}$ Hourly wages are calculated by dividing weekly gross wages and salary from main job by usual hours worked per week in main job. Wages are converted to 2001 dollars using the consumer price index.
} 
similarities in growth rates do not indicate a zero gender wage gap in this sample. On the contrary, there exists an average wage gap of approximately 10 percent. The difference in wage levels between genders is likely due to the dissimilarity in occupations/industries of lower skilled men and women. For example, many male high school dropouts (eventually) find work in skilled trades, whereas far fewer female high school dropouts find skilled employment.

Figure 2 shows a remarkable difference in the wage growth of university educated men and women. From labour force entry to around 20 years of experience, men obtain much larger wage increases than women. ${ }^{5}$ This difference in wage growth is the cause of the large gender wage gap for university-educated employees, because at labour force entry university-educated men and women receive similar wages - log wages for men equal 2.87 and log wages for women equal 2.86. This pattern concurs with the findings in Kee (2006) and Baron and Cobb-Clark (2008) which suggest that the Australian gender wage gap is higher for high skill workers. It is also similar to the gender gap in early career wage growth for British workers. Manning and Swaffield (2008) show using BHPS data that British men and women earn very similar wages on entry to the labour market, but that a gender gap quickly emerges and grows to its maximum after about 20 years experience.

To investigate the role that job mobility may play in generating the patterns of Figures 1 and 2, we plot promotion rates in Figure 3. The somewhat startling result is the size of the gap in promotion rates between university-educated males and females. In their first 10 years of working, men appear to have around a 10 percentage point greater chance of being promoted than women, and this gap only closes after about 20 years of working. Interestingly, the gender gap in promotion rates matches up closely with the gender gap in wage growth displayed in Figure 2. Though of course we should be tentative about drawing any firm conclusions from descriptive data, the results suggest that differences in promotion rates may play a role in generating gender differences in the wage growth for less-experienced university-educated workers. Consistent with the lack of a wage growth gender gap for non-university-educated workers, Figure 3 shows no significant differences in promotion rates for men and women without university degrees.

\footnotetext{
${ }^{5}$ The wage growth differences presented in Figure 2 could be biased by cohort effects; however, as shown by Manning and Swaffield (2008) for the UK, it is unlikely that they are the primary reason for the widening of the gender pay gap after labour force entry.
} 
If the descriptive evidence is to be believed, differences in employer change rates seem to play a less significant role in generating the patterns of Figures 1 and 2. Figure 4 shows only small differences in the probability of changing employers between men and women, and between university-educated workers and non-university-educated workers. The most prevalent gender differences occur in the first few years of working; but, even for these workers the differences are many times smaller than observed for promotions.

For the remainder of this paper we focus on the subsample of university-educated workers with less than 20 years experience. This decision is motivated by the graphical patterns we observe in Figures 1 to $4 .{ }^{6}$ It also motivated by two common findings: (i) the gender wage gap is higher for high skill workers (e.g. Kee, 2006; Baron and Cobb-Clark, 2008), and (ii) wage growth in the early years after labour market entry is a primary driver of the overall gender pay gap (e.g. Manning and Swaffield, 2008). In Table 1 we present descriptive statistics for our chosen subsample by gender. The first four rows summarise the main findings from Figures 2, 3 and 4: less-experienced, university-educated men have significantly higher wages and wage growth, significantly higher promotion rates, and similar employer-change rates to women. Table 1 also shows that there are significant gender differences in experience, education, hours worked, employment sector, occupation, industry and personality. In Section 4, we examine whether the gender differences in these observable characteristics can explain some or all of the observed differences in job mobility.

\section{Results}

\subsection{The Gender Gap in Job Mobility}

In this section, we determine whether women are promoted as frequently as men. Following Booth et al. (2003), Blau and DeVaro (2007) and others in the literature, we estimate probit promotion models, focusing on the estimated effect of gender and how it changes across specifications that control for increasingly large sets of covariates. Where we differ from previous studies is that instead of estimating pooled probit models, we exploit the longitudinal

\footnotetext{
${ }^{6}$ We have repeated the regression analysis contained in the following sections for the other three groups looked at in the descriptive section: without degree $<20$ years experience, without degree $>20$ years experience, and with degree $>20$ years experience. The regressions results agree with the descriptive results. Namely, less-experienced, degree-holders are the only group for which there exists a large, significant gender gap in promotions and the only group for which there exists a large, significant gender gap in the returns to promotions.
} 
structure of our data and estimate random effects probit models. ${ }^{7}$ In our baseline model, shown in the first column of Table 2, we include only the standard human capital variables: experience, experience squared and education, and also year dummy variables to control for any economywide labour market changes. We report only the estimated effect of gender, however, as the control variables are not of primary interest and their effects are similar to those found in previous studies (e.g. experience increases the probability of being promoted but at a decreasing rate). Clustered standard errors for the gender effect are presented in order to control for the dependence between observations for the same individual over time. The estimated female coefficient for the baseline model indicates that women are 7.9 percentage points less likely to be promoted. Given that the average promotion rate for our sample is 19.9 percent, this constitutes a very large effect.

In specification two, we include controls for full-time employment status, public sector job and union membership. These controls are likely to be important because women are less likely to work full-time, and more likely to be employed in the public sector and to belong to a union. Furthermore, previous studies have shown that the gender gap differs between public and private, and unionized and non-unionized sectors (e.g. Baron and Cobb-Clark, 2008). The estimated gender coefficient for this specification is shown in column 2 and suggests that women are 4.5 percentage points less likely to be promoted; a 3.4 percentage point reduction from the baseline model.

A prominent explanation for gender gaps in wages and promotions is that men and women have different occupations, work in different industries and are employed by different types of firms. In specification three, we explore this explanation by adding 19 dummy variables characterizing firm size, occupation and industry. The gender gap in this specification is further reduced to 2.9 percentage points. It is important to note, however, that these variables are potentially endogenous. For example, a woman may avoid a particular industry because she expects she'll be discriminated against. For this reason, Albrecht et al. (2003) suggested that estimates from models with occupation and industry controls should be viewed as a lower bound for the extent of discrimination. Another potential explanation for gender differences in promotions is that women allocate more time and effort than men into non-work commitments,

\footnotetext{
${ }^{7}$ The results presented in Table 2 are not sensitive to our estimation approach. For example, if we use pooled probit models instead of random effects probit models, the estimated gender effects are all very similar to those presented. In model (5), the female effect equals -0.037 , with standard error 0.013 .
} 
such as child rearing. In specification four, we additionally control for relationship status, number of children and expectations of having children in the future. Rather than decreasing the estimated gender gap as may be expected, these additional controls work to increase the gap to 3.7 percentage points.

In the last column, we attempt to determine if 'psychological' theories can help explain the gender gap in promotions. Previous studies suggest that there exist large correlations between earnings and personality types (see, for example, Goldsmith et al., 1997; Bowles et al., 2001; Nyhus and Pons, 2005) and a large literature documents important personality differences between genders. Our results suggest that the well-known 'five-factor' model of personality has little effect on the estimated gender difference in promotion rates. ${ }^{8}$ While it is possible that the five-factor model does not fully capture the rich heterogeneous personalities of individuals, Manning and Swaffield (2008) find, using a much broader set of personality variables than we have at our disposal, that psychological theories do not explain much of the gender wage gap. Thus, the main conclusion we draw from Table 2 is that women are less likely to be promoted than men, and that this gap exists even after controlling for a host of individual and job characteristics that affect promotions. ${ }^{9}$

An important issue for the interpretation of the estimated effects in Table 2 is sample selection; in particular, the selectivity of women into the labour force. Our subsample of lessexperienced, university degree holders, who work full-time in at least one wave, is likely to have particularly strong labour force attachment, which suggests that the included females are likely to be more positively selected than the included males for whom full-time employment (especially in their 30s) is more common. Furthermore, it's likely that the career and promotion prospects of these women are greater on average than the women who have chosen to leave the work force or work solely part-time. If these propositions are correct then our estimates of the gender wage gap

\footnotetext{
${ }^{8}$ The five factor model of personality is an important conceptualization of personality in contemporary psychology. Comprising of five domains - extroversion, agreeableness, conscientiousness, neuroticism and openness to experience - it has been reproduced in a number of culturally different countries, which is suggestive of a universally valid structure (e.g. see McCrae and Terracciano, 2005).

${ }^{9}$ In order to determine the sensitivity of our results to our chosen sample restrictions, we re-estimated the probit models contained in Table 2 for a subsample of full-time workers only. The estimated gender gaps are broadly consistent with those presented: model (1) equals -0.047 ; model (2) equals -0.040 ; model (3) equals -0.026; model (4) equals -0.036; and model (5) equals -0.035. The estimates are however not statistically significant in most instances, which is likely due to the reduction in sample size. Given that chosen hours worked may be partially determined by promotion prospects (i.e. endogenous), we favor the estimates in Table 2 that are based on a sample of workers with strong attachment to the labor force, but who are not necessarily always full time employed.
} 
will be downwards biased, i.e. the gap would actually be bigger if we included women who have become discouraged by the lack of career opportunities.

Table 3 examines the related issue of whether women change employers as frequently as men. Columns one to five in Table 3 are based on the exact same specifications as used in columns one to five in Table 2, with the only difference being that the dependent variable is instead an indicator for whether the individual has changed employers in the past 12 months. Here, it can be seen that there are no significant gender differences in employer change rates for university educated employees; specifications one to five all return small, non-significant coefficients on the female dummy variable.

An interpretation of these results is that while promotions always constitute increases in job levels, employer changes sometimes constitute lateral changes and even decreases in job levels. It is possible then that men are significantly more likely than women to increase job levels through employer changes (similar to our promotion results), whereas women are more likely to change employers at the same or even lower job levels. We explored this possibility by reestimating probit model (5) with two alternative binary outcomes: (i) employer change with promotion and (ii) employer change without promotion $(15.0 \%$ of employer changes are with a promotion). The estimated female effect equals -0.002 for outcome (i) and 0.012 for outcome (ii), with both estimates statistically insignificant. Our tentative conclusion from these results is that the results in Table 3 are not driven by systematic gender differences in the types of employer changes. ${ }^{10}$

Why are women less likely to be promoted? Perhaps women are more satisfied with their current roles and so are less likely to apply for promotions and new jobs. In Table 4, we investigate this hypothesis by estimating panel data models using a series of alternative outcomes. The first outcome is an indicator for whether the worker has looked for a new job during the past 4 weeks. We find no significant gender differences in this outcome when we estimate a random effects probit model controlling for our full set of individual and job characteristics. Similarly, the second row of Table 4 shows that there are no gender differences

\footnotetext{
${ }^{10} \mathrm{We}$ are less confident in the reliability of our data to separately identify employer changes with and without promotions. Some respondents who changed employers to a higher job level will have indicated in the survey interview that they changed employers and received a promotion. However, it is likely that many others will only indicate that they changed employers.
} 
in whether the individual has applied for a new job in the past 2 years. Both results suggest that women are equally willing to climb the job ladder as men.

We next turn our focus to a series of job satisfaction outcomes. All employed HILDA survey respondents are asked to "pick a number between 0 and 10 to indicate how satisfied or dissatisfied you are with the following aspects of your job" and that "the more satisfied you are, the higher the number you should pick." The job aspects listed are: total pay, job security, the work itself (what you do), the hours you work, the flexibility available to balance work and nonwork commitments, and overall satisfaction. Table 4 presents results from linear random effects models, and shows that after controlling for individual and job characteristics, there are no gender differences in satisfaction with work content and the job as a whole. These results suggest that women and men enjoy their jobs to a similar extent, and are inconsistent with the hypothesis that women are less likely to apply for new jobs because they are more satisfied in their current roles. There are, however, significant gender gaps in satisfaction with work-life balance (at the 10 percent level) and in satisfaction with hours worked (at the 5 percent level). The significantly negative coefficients indicate that women would like to work fewer hours in order to devote more time to non-work commitments. This finding suggests that some women may be unwilling to tolerate excessive work hours, particularly the long hours expected in some high level jobs, and so be less likely to apply for promotions and less likely to receive promotions. This mechanism is likely to be especially true in particular industries. For example, Landers et al. (1996) show that law firms use work hours as an indicator of performance and is hence an important factor in promotion decisions.

\subsection{Effects of Job Changes on Wages, Satisfaction and Time Use}

In addition to differences in the rate of promotions, female average wage levels may be lower than male wage levels because they receive lower wage increases when promoted or when changing employers. Exploiting the longitudinal nature of our data set, we examine this issue by estimating fixed effects regressions of log wages that include either promotion or employerchange indicators, as well as their interactions with a female dummy. The estimated coefficients on the promotion indicator and the female interaction term are displayed in columns one and two in the first row of Table 5. The coefficients for the other control variables in the model are not reported in the table. The results suggest that promotions are associated with an $8.7 \%$ increase in 
hourly wages; ${ }^{11}$ however, the gender-promotion interaction term is negative, indicating that women receive significantly lower (though still positive) wage increases when promoted. In other words, even if men and women received an equal number of promotions, the gender wage gap would still grow over time because men receive larger wage increases with each promotion. Columns three and four in the first row of Table 5 present similar results for employer changes. The results suggest that employer changes for men are associated with a 3.3\% increase in hourly wages, but that women receive significantly lower wage increases when changing employers. In fact, for employer changes women receive a wage cut - an F-test indicates that the sum of the main effect and interaction term (-2.3 log points) is significantly different from zero at the 5 percent level. This result suggests that women are more likely than men to experience negative changes in job levels when changing employers. ${ }^{12}$

A potential explanation for the lower wage increases received by women, especially when changing employers, is that some women trade away wages for non-monetary rewards. For example, some women may move to a lower job level so that they can work fewer hours or so that they can have greater flexibility to balance work and non-work commitments. We examine this explanation by re-estimating our fixed effects models using several alternative dependent variables, such as satisfaction with different aspects of work, as well as hours spent on work and domestic activities. The results of these regressions are shown in rows three to thirteen in Table 5.

As one might expect, for both men and women promotions and employer changes are positively associated with satisfaction with work content and overall job satisfaction. These findings reflect the underlying motivation for changing jobs. We also find promotions are positively related to hours worked in main job and negatively related to time spent doing housework. This likely reflects the fact that employees are often required to work longer hours at higher job levels. Most importantly, we find that none of the interaction terms in the models for satisfaction and time use are statistically significant. This suggests that after changing employers, women have similar satisfaction as men with their hours worked, with their work-life balance and with their work content. The results also suggest that after changing employers, men and

\footnotetext{
${ }^{11}$ This is calculated using the standard formula of $100\left(\mathrm{e}^{\beta}-1\right)$, where $\beta$ is the difference in log points of 0.083 .

${ }^{12}$ The estimated gender interaction effects are similar if we restrict our sample to full-time workers only. For example, the log hourly wage interaction effect for promotions and job changes equals -0.066 and -0.052 , respectively, with both effects significant at the $1 \%$ level.
} 
women experience similar increases in hours worked. Thus, we do not find any evidence to support the hypothesis that women trade away wages when changing employers in exchange for non-monetary rewards.

\section{Discussion}

In the above empirical analysis we document a substantial gender gap for less-experienced (experience $<20$ years), university educated workers in the probability of promotion, and in the economic returns to promotions and employer changes. We also investigate prominent explanations for the gender gaps. Our results suggest that observable differences in human capital, family status and personality are not causing the gap. In addition, it does not appear that women are more content with their current roles than men, or that women substitute wages for improved working conditions when they are promoted or when they change employers. Given these findings, we review in this subsection some alternative explanations for our results. In particular, we discuss theories related to discrimination and theories related to psychological differences between genders.

Differences in promotion rates could arise because of widespread prejudice against women. For example, it is possible that our results are caused by employers preferring to promote men over women with higher expected productivity because employers find it 'distasteful' to work with women (taste-based discrimination). However, such widespread sexism seems unlikely. As explained in Section 2, it is illegal in Australia to discriminate against someone on the basis of gender and there would be substantial public relations costs associated with being revealed as a sexist employer. It is possible though that women suffer from statistical discrimination as opposed to taste-based discrimination (Phelps, 1972; Aiger and Cain, 1977). Statistical discrimination arises when employers are unable to observe a worker's true productivity, but are able to observe a worker characteristic that is correlated with or signals a worker's productivity. For example, if in the experience of an employer, women are likely to have multiple extended absences from work due to child bearing, then the employer may favour a male candidate over an equally qualified female candidate in order to avoid hiring or promoting an employee who may require a lengthy leave of absence in the future. Such statistical discrimination may also be self-reinforcing if women are aware of the existence of statistical 
discrimination in advance, as it may discourage even well qualified women from investing in skills, or from applying for promotions and wage increases.

A recent paper by Bjerk (2008) extends the static theoretical model in the classical statistical discrimination literature by including a dynamic element. In his model, firms use information they observe over the whole course of the worker's career to attempt to infer their type. He shows that gender gaps in labor market outcomes can arise due to an inequality of opportunity for promotions. According to Bjerk (2008), this inequality arises if: there are fewer highly skilled women than men; if skill signals emitted by women are evaluated less precisely by firms than skill signals emitted by men; and if women generally have fewer opportunities to signal their skill prior to starting their career or early in their career. Together, these group differences result in a longer period of time and effort for women to be promoted than equally skilled men.

DeVaro et al. (2007) outline an alternative discrimination model based on asymmetric information about worker ability and job assignment signalling (Milgrom and Oster, 1987). In this model, males are more likely to be recognized for their abilities by potential employers than women - for example, males may be more likely to publicise themselves, to attend out-of-town conventions, and to benefit from "old boys' club" connections, all of which make their skills more visible to prospective employers. This informational asymmetry means that other employers in the market use women's job assignment or rank as a signal of their ability, allowing a woman's current employer - who observes her productivity perfectly - to earn excess profits by denying her promotions. This discriminatory process is expected to be particularly prominent in firms where tasks vary little across hierarchical levels, as for such jobs the opportunity cost to the employer of not promoting highly productive women is lower.

An interesting alternative economic theory explaining the glass ceiling has been put forth by Grout et al. (2009). In their two period model, period 1 represents the period of initial employment in which workers decide on their human capital investment, and period 2 is the period in which workers obtain either a low-tier job or an upper-tier job. Men and women are assumed to have equal productivity in period 1, but Grout et al. (2009) show that despite this equality, women will be offered inferior promotion deals than men and earn lower wages. The key assumption driving this result is that females are heterogeneous in the value of their nonmarket options, whereas males do not encounter such non-market options. They show that the 
existence of more "family-oriented" women who respond to such non-market options in period 1 imposes a negative externality to career track women and can lead to disadvantaged treatment suffered by women in upper tier jobs in period 2.

Our empirical results could also be explained by fundamental psychological differences between men and women, which manifest themselves in a lower average desire or ability by women to climb the job ladder. For example, women may be less fond on average of jobs that require confrontation with other employees. Alternatively, women may be unwilling to compete and bargain as aggressively as men when seeking promotions and raises (Babcock and Laschever, 2003). Recently, a growing economics literature has found that there does exist a number of significant psychological differences between genders. Booth and Nolen (2009a), Sapienza et al. (2009) and many others find that women are more risk averse than men (for a review see Eckel and Grossman, 2008). This risk-aversion could lead to the attraction of women to jobs with lower-mean, lower-variance salaries. For example, due to higher risk aversion women may be less likely to apply for high-level jobs in which remuneration is based on company performance. Similarly, Gneezy et al. (2003), Niederle and Vesterlund (2007) and Booth and Nolen (2009b) find that women are less willing to enter competitive environments. For example, Niederle and Vesterlund (2007) examine compensation choices in an environment where men and women are equally good at competing. They find that the majority of men select the competitive tournament whereas the majority of women select the non-competitive piece rate. Finally, Dreber and Johannesson (2008) find that women lie less frequently then men in order to secure monetary payoffs. Limited evidence exists as to the extent to which the observed gender differences are determined by biological or cultural differences; however, it has been shown that behaviour in economic experiments can vary considerably across cultures (Gneezy et al., 2009) and even between single-sex and co-educational schools (Booth and Nolen, 2009a), suggesting that cultural factors may play a role.

\section{Conclusion}

Are there significant gender differences in the probability of receiving a promotion and in the wage changes related to promotions? Similarly, are there significant gender differences in the probability of changing employers and in wage changes associated with employer changes? Finally, can any gender differences in mobility be explained by gender differences in job 
preferences? To answer these questions, we analyse a sample of university-educated workers with less than 20 years experience who have taken part in an Australian longitudinal survey. We find that women are much less likely to be promoted than men, and that women receive significantly lower wage increases when promoted. Although there are no gender differences in terms of employer change rates, women are on average receiving a wage penalty when changing employers. Thus, our findings suggest that the dynamics of both promotions and employer changes in Australia exacerbate the gender wage gap. We also find that after receiving promotions and changing employers, women have similar satisfaction as men with their hours worked, with their work-life balance and with their work content, and experience similar changes in their time use. Therefore, the hypothesis that women value non-monetary aspects of work more highly than men and so consequently choose jobs that allow them to allocate more time to other activities, is not supported by our data. 


\section{References}

Aiger, D. and G. Cain. (1977). "Statistical Theories of Discrimination in the Labor Market." Industrial and Labor Relations Review, 30: 175-187.

Albrecht, J., A. Bjorklund and S. Vroman. (2003). "Is There a Glass Ceiling in Sweden?" Journal of Labor Economics, 21: 145-177.

Arulampalam, W., A. Booth and M. Bryan. (2007). "Is There a Glass Ceiling over Europe? Exploring the Gender Pay Gap Across the Wages Distribution." Industrial \& Labor Relations Review, 60: 163-186.

Babcock, L. and S. Laschever. (2003). Women Don't Ask: Negotiation and the Gender Divide. Princeton University Press: Princeton NJ.

Barnett, W., J. Baron and T. Stuart. (2000). "Avenues of Attainment: Occupational Demography and Organizational Careers in the California Civil Service." American Journal of Sociology, 106: 88-144.

Bjerk, D. (2008). "Glass Ceilings or Sticky Floors? Statistical Discrimination in a Dynamic Model of Hiring and Promotion." The Economic Journal, 118: 961-982.

Booth, A. (2007). "The Glass Ceiling in Europe and Australia: Why Are Women Doing Badly in the Labour Market?” Unpublished manuscript.

Booth, A. (2009). "Gender and Competition.” Labour Economics, 16: 599-606.

Booth, A., F. Marco and F. Jeff. (2003). "A Sticky Floors Model of Promotion, Pay and Gender.” European Economic Review, 47: 295-322.

Booth, A. and P. Nolen. (2009a). "Gender Differences in Risk Behaviour: Does Nurture Matter?" IZA Discussion Papers 4026, Institute for the Study of Labor (IZA)

Booth, A. and P. Nolen. (2009b). "Choosing to Compete: How Different are Girls and Boys." IZA Discussion Papers 4027, Institute for the Study of Labor (IZA)

Borland, J. (1999). “The Equal Pay Case - Thirty Years On.” Australian Economic Review, 323 : 265-272.

Blau, F. and L. Kahn. (2000). "Gender Differences in Pay." Journal of Economic Perspectives, 14: 75-99.

Blau, F and J. DeVaro. (2007). "New Evidence on Gender Differences in Promotion Rates: An Empirical Analysis of a Cross Section of Establishments." Industrial Relations, 46: 511-550. 
Bowles, S., H. Gintis and M. Osborne. (2001). "The Determinants of Earnings: a Behavioural Approach.” Journal of Economic Literature, 39: 1137-1176.

Cobb-Clark, D. (2001). "Getting Ahead: The Determinants of and Payoffs to Internal Promotion for Young U.S. Men and Women." In Worker Well-Being in a Changing Labor Market, Research in Labor Economics, edited by Solomon W. Polachek, pp. 339-372. New York: JAI Elsevier Science.

DeVaro, J., S. Ghosh and C. Zoghi. (2007). "Job Characteristics and Labor Market Discrimination in Promotions: New Theory and Empirical Evidence." ILR Working Paper 5.

Dreber, A. and M. Johannesson. (2008). "Gender Differences in Deception.” Economics Letters, 99: 197-199.

Eastough, K. and P. Miller. (2004). "The Gender Wage Gap in Paid- and Self-Employment in Australia." Australian Economic Papers, 43: 257-276.

Eckel, C. and P. Grossmann. (2008). "Men, Women and Risk Aversion: Experimental Evidence.” In Plott, C., and V. Smith, Handbook of Experimental Results.

Giuliano, L, D. Levine, and J. Leonard. (2005). "Do Race, Gender, and Age Differences Affect Manager-Employee Relations? An Analysis of Quits, Dismissals, and Promotions at a Large Retail Firm.” Unpublished manuscript.

Goldsmith, A., J. Veum and W. Darity. (1997). "The Impact of Psychological and Human Capital on Wages.” Economic Inquiry, 35: 815-829.

Grout, P., I. Park and S. Sonderegger. (2009). “An Economic Theory of Glass Ceiling.” CMPO Working Paper No. 09/227.

Gneezy, U., M. Niederle and A. Rustichini. (2003). "Performance in Competitive Environments: Gender Differences.” Quarterly Journal of Economics, August: 1049-1074.

Gneezy, U., K. Leonard, J. List. (2009). "Gender Differences in Competition: Evidence from a Matrilineal and a Patriarchal Society." Econometrica, 77: 1637-1664.

Gregory, R. (1999). "Labour Market Institutions and the Gender Pay Ratio." Australian Economic Review, 32: 272-278.

Hersch, J. and W. Viscusi. (1996). "Gender Differences in Promotions and Wages." Industrial Relations, 35: 461-472.

Jones, D. and G. Makepeace. (1996). "Equal Worth, Equal Opportunities: Pay and Promotion in an Internal Labour Market.” Economic Journal, 106: 401-409. 
Kee, H. J. (2006). "Glass Ceiling or Sticky Floor? Exploring the Australian Gender Pay Gap." The Economic Record, 82: 408-427.

Landers, R., J. Rebitzer and L. Taylor. (1996). "Rat Race Redux: Adverse Selection in the Determination of Work Hours in Law Firms." American Economic Review, 86: 329-348.

Le, A. and P. Miller. (2010). "Glass Ceiling and Double Disadvantage Effects: Women in the US Labour Market.” Applied Economics, 42: 603-613.

Manning, A and J. Swaffield. (2008). "The Gender Gap in Early-Career Wage Growth." Economic Journal, 118: 983-1024.

McCue, K. (1996). "Promotions and Wage Growth.” Journal of Labor Economics, 14: 175-209.

McCrae R. and A. Terracciano. (2005). "Universal Features of Personality Traits from the Observer's Perspective: Data from 50 Countries." Journal of Personality and Social Psychology, 88: 547-561.

Milgrom, P. and S. Oster (1987). "Job Discrimination, Market Forces, and the Invisibility Hypothesis." Quarterly Journal of Economics, 102: 453-476.

Miller, P. (1994). "Effects on Earnings of the Removal of Direct Discrimination in Minimum Wage Rates: a Validation of the Blinder Decomposition." Labour Economics, 1: 347-363.

Niederle, M. and L. Vesterlund. (2007). "Do Women Shy Away From Competition? Do Men Compete Too Much?" Quarterly Journal of Economics, 122: 1067-1101.

Nyhus, E. and E. Pons. (2005). "The Effects of Personality on Earnings." Journal of Economic Psychology, 26: 363-384

Paulin, E. and J. Mellor. (1996). "Gender, Race, and Promotions within a Private-Sector Firm." Industrial Relations. 35: 276-295.

Pekkarinen, T. and J. Vartiainen. (2006). "Gender Differences in Promotion on a Job Ladder: Evidence from Finnish Metalworkers." Industrial and Labor Relations Review, 59: 285-301.

Phelps, E. (1972). "The Statistical Theory of Racism and Sexism.” American Economic Review, 62: 659-661.

Preston, A. and G. Crockett. (1999). "Equal Pay: Is the Pendulum Swinging Back?” Journal of Industrial Relations, 41: 561-574.

Ransom, M. and R. Oaxaca. (2005). "Intrafirm Mobility and Sex Differences in Pay." Industrial and Labor Relations Review, 58, article 3. 
Sapienza, P., L. Zingales and D. Maestripieri. (2009). "Gender Differences in Financial Risk Aversion and Career Choices are Affected by Testosterone." Proceedings of the National Academy of Sciences of the United States, forthcoming.

Weichselbaumer, D. and R. Winter-Ebmer. (2005). "A Meta-Analysis of the International Gender Wage Gap.” Journal of Economic Surveys, 19: 479-511.

Winter-Ebmer, R. and J. Zweimuller. (1997). "Unequal Assignment and Unequal Promotion in Job Ladders." Journal of Labor Economics, 15: 43-71. 
Figure 1: Annual Change in Real Log Hourly Wages of Employees without University Degrees

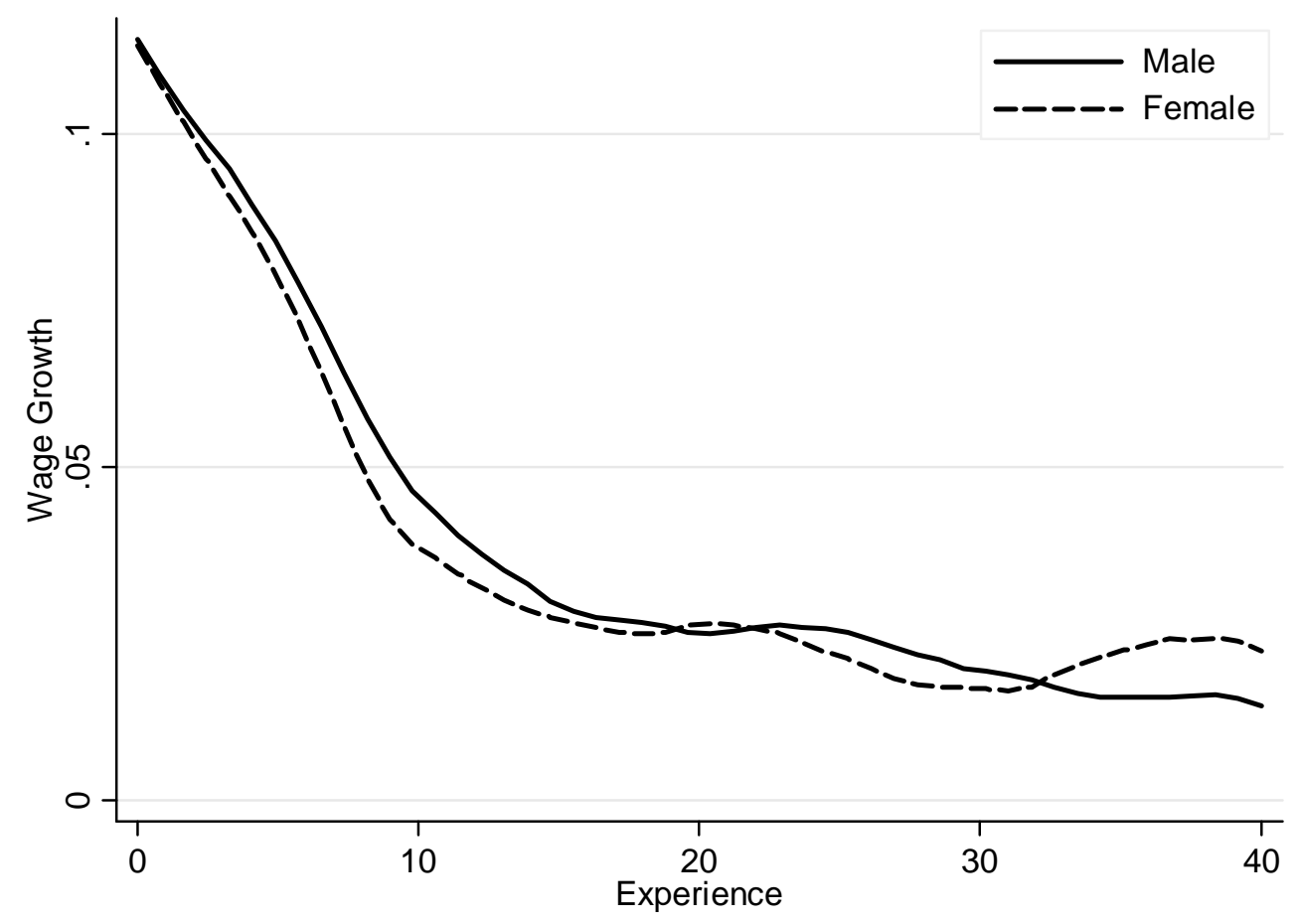

Figure 2: Annual Change in Real Log Hourly Wages of Employees with University Degrees

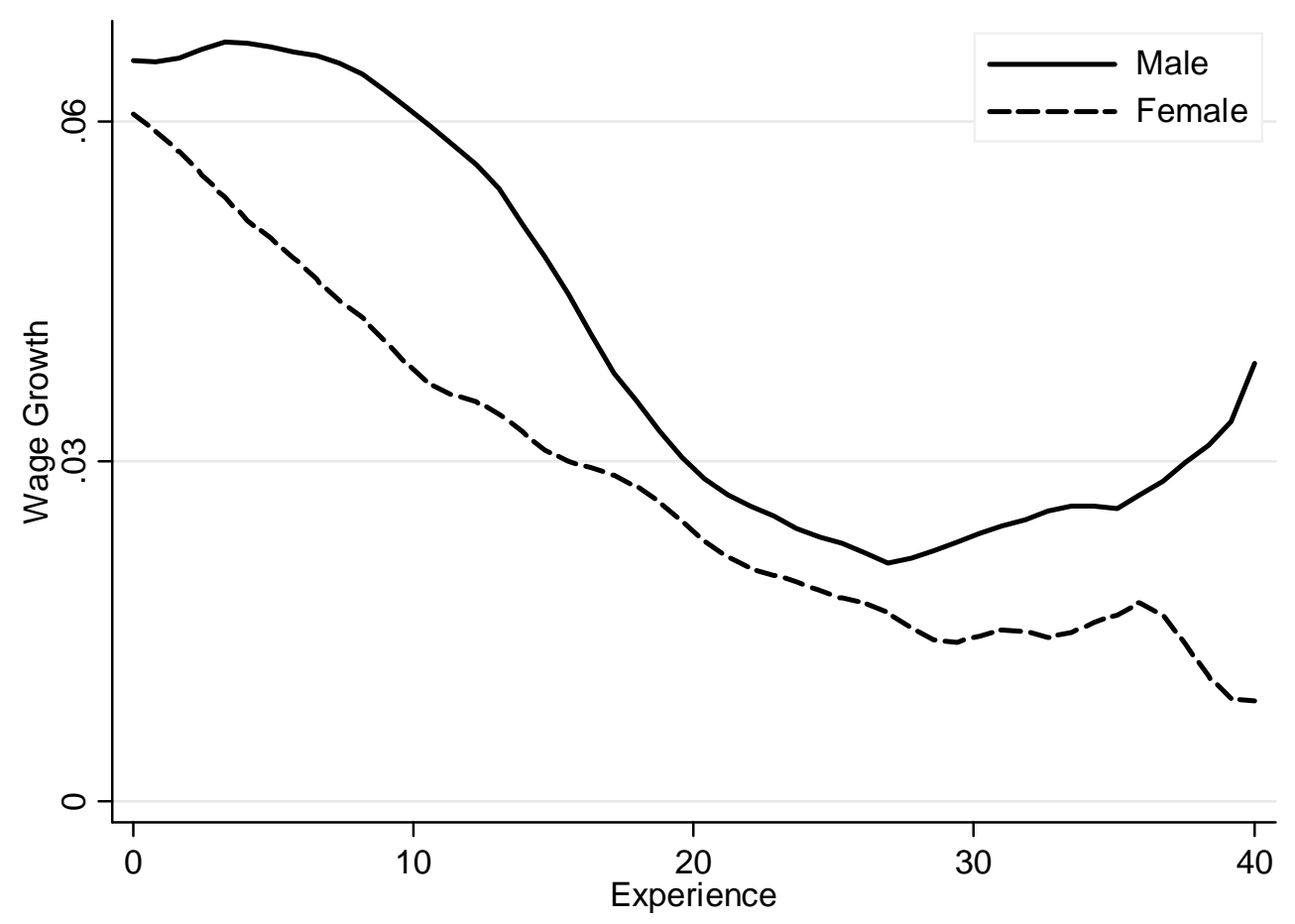


Figure 3: Probability an Employee received a Promotion in the past 12 months

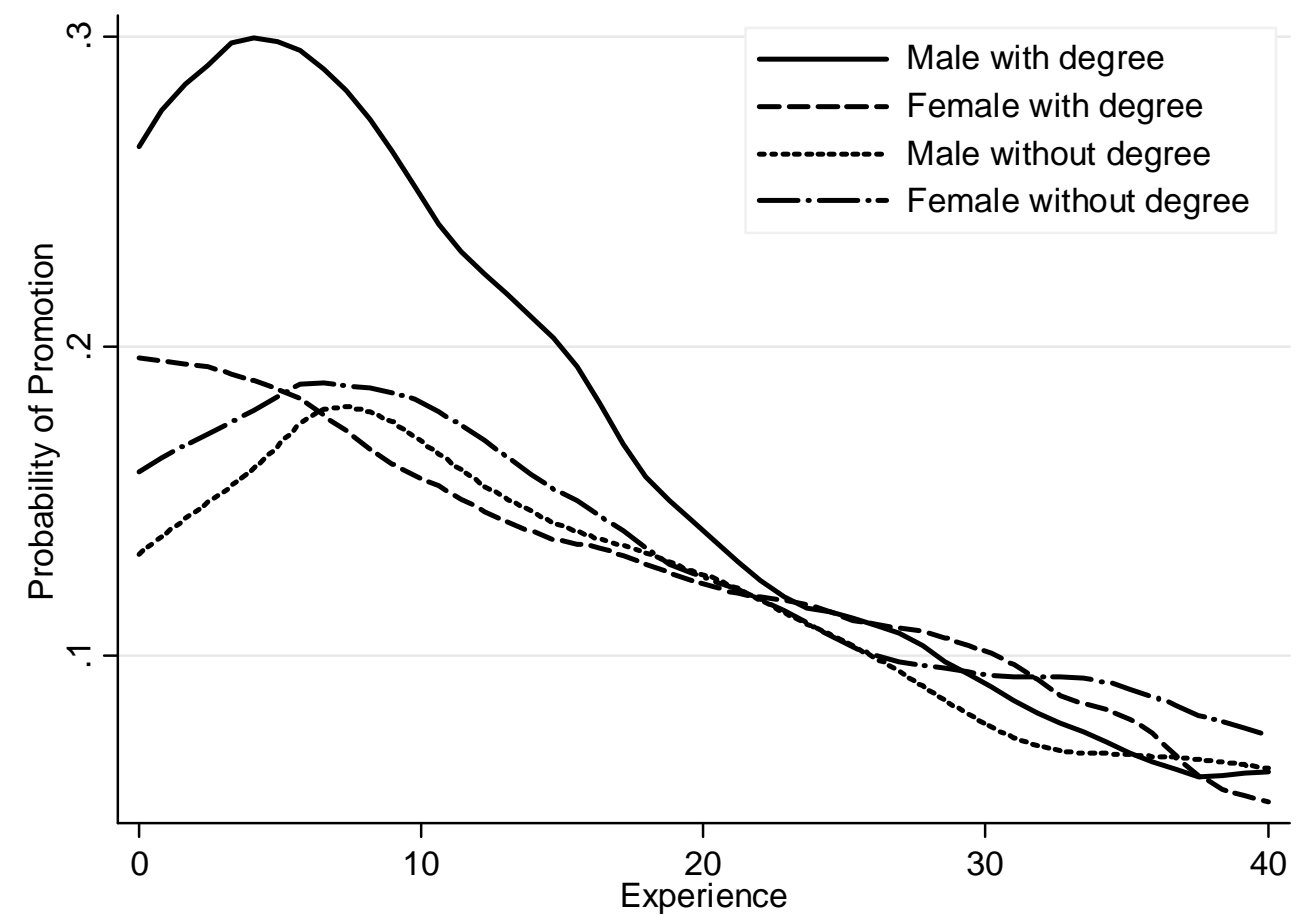

Figure 4: Probability an Employee changed Employers in the past 12 months

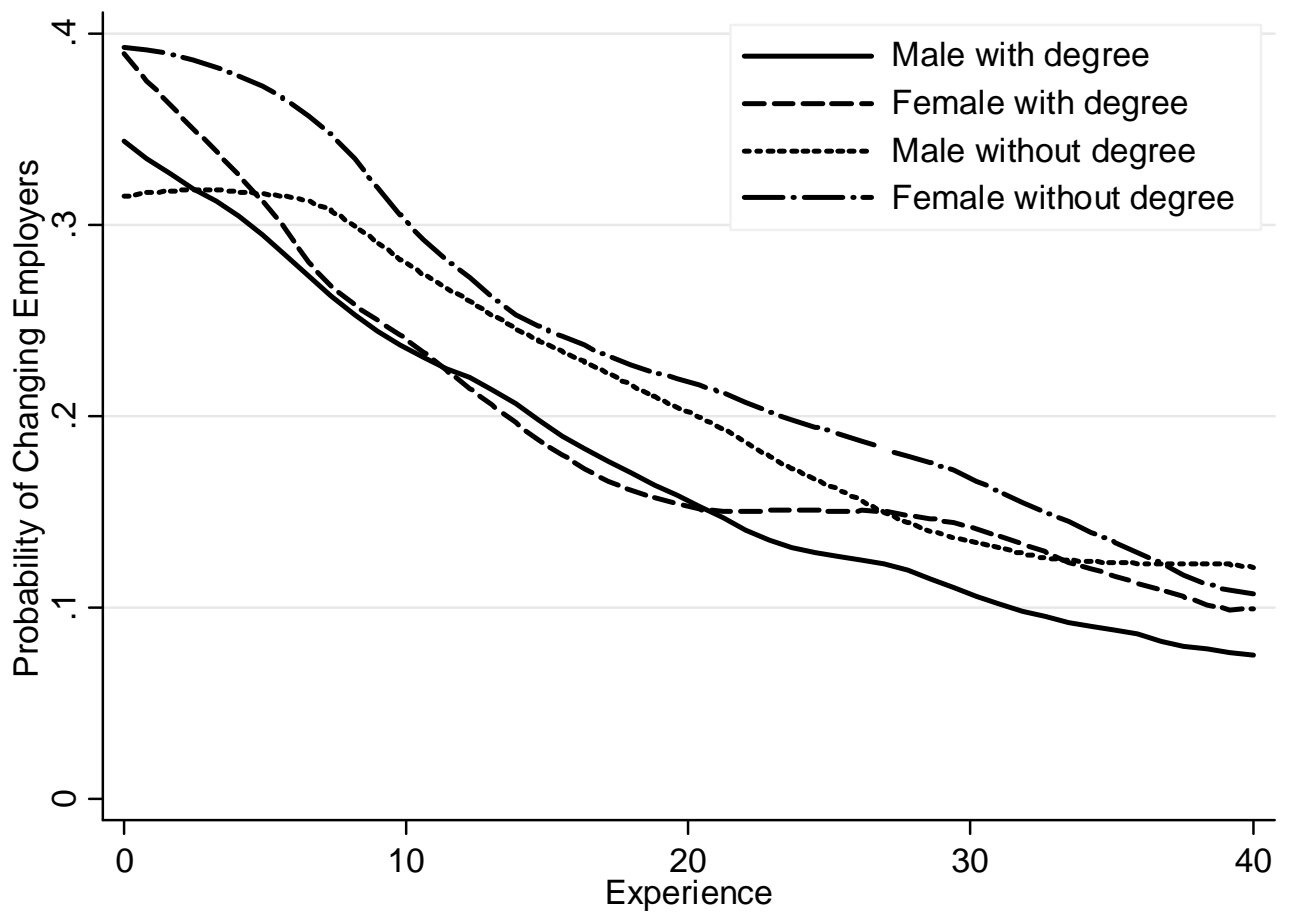


Table 1: Means of Selected Characteristics for University Graduates with $<20$ Years Experience

\begin{tabular}{|c|c|c|}
\hline & Males & Females \\
\hline Real log hourly wage & 3.204 & $3.060 * *$ \\
\hline Annual real hourly wage growth & 0.061 & $0.040 * *$ \\
\hline Promotion & 0.239 & $0.165 * *$ \\
\hline Employer change & 0.246 & 0.268 \\
\hline Hours work per week & 44.107 & $37.704 * *$ \\
\hline Job satisfaction (0-10 scale) & 7.428 & 7.454 \\
\hline Experience & 9.964 & $8.753 * *$ \\
\hline Postgraduate degree & 0.144 & $0.102 *$ \\
\hline Postgraduate diploma & 0.170 & 0.190 \\
\hline Employed full-time & 0.938 & $0.751 * *$ \\
\hline Member of a trade union & 0.220 & $0.341 * *$ \\
\hline Employed in public sector & 0.315 & $0.476 * *$ \\
\hline Employed in a managerial occupation & 0.195 & $0.100 * *$ \\
\hline Employed in a professional occupation & 0.585 & $0.678 * *$ \\
\hline Employed in education/health industries & 0.197 & $0.501 * *$ \\
\hline Employed in a firm with less than 10 employees & 0.114 & 0.116 \\
\hline Employed in a firm with 10-50 employees & 0.285 & 0.287 \\
\hline Employed in a firm with 50-200 employees & 0.258 & 0.266 \\
\hline Married or cohabitating & 0.700 & 0.688 \\
\hline Divorced or separated & 0.026 & 0.037 \\
\hline Number of children aged $0-4$ years & 0.402 & $0.260 * *$ \\
\hline Number of children aged 5-9 years & 0.221 & $0.170 *$ \\
\hline Number of children aged 10-14 years & 0.099 & 0.128 \\
\hline Likelihood of having (more) children ( $0-10$ scale) & 5.416 & 5.630 \\
\hline Extroversion personality scale & 4.288 & $4.670 * *$ \\
\hline Agreeableness personality scale & 5.222 & $5.598 * *$ \\
\hline Conscientiousness personality scale & 5.086 & $5.239 * *$ \\
\hline Emotional stability personality scale & 5.097 & 5.102 \\
\hline Openness to experience personality scale & 4.556 & 4.457 \\
\hline Sample size & 2605 & 3083 \\
\hline
\end{tabular}

Notes: Means calculated using a pooled sample of the eight data waves. Stars denote significant difference between the sample mean of males and females (calculated using clustered standard errors). ${ }^{*}$ and ${ }^{* *}$ denote significance at .05 and .01 levels. 
Table 2: Estimates of Gender Gap in Promotions Rates for University Graduates with $<20$ Years Experience - Random Effects Probit Models

\begin{tabular}{lccccc}
\hline & $(1)$ & $(2)$ & $(3)$ & $(4)$ & $(5)$ \\
\hline Female effect & $-0.079^{* *}$ & $-0.045^{* *}$ & $-0.029^{*}$ & $-0.037^{* *}$ & $-0.034^{*}$ \\
& $(0.014)$ & $(0.014)$ & $(0.014)$ & $(0.014)$ & $(0.014)$ \\
Included control variables & & & & & $\checkmark$ \\
Year controls (6) & $\checkmark$ & $\checkmark$ & $\checkmark$ & $\checkmark$ & $\checkmark$ \\
Experience, education (4) & $\checkmark$ & $\checkmark$ & $\checkmark$ & $\checkmark$ & $\checkmark$ \\
Employment type (3) & & $\checkmark$ & $\checkmark$ & $\checkmark$ & $\checkmark$ \\
Firm size, occupation, industry (19) & & $\checkmark$ & $\checkmark$ & $\checkmark$ \\
Family status, child expectations (6) & & & $\checkmark$ & $\checkmark$ \\
Personality (5) & -2701.5 & -2644.2 & -2599.1 & -2588.9 & -2584.4 \\
Log likelihood & 5688 & 5688 & 5688 & 5688 & 5688 \\
Sample size & & & & $\checkmark$ \\
\hline
\end{tabular}

Note: Marginal effects calculated at the mean values of the explanatory variables. Models are estimated using 24 quadrature points. ${ }^{*}$ and $* *$ denote significance at .05 and .01 levels. Sets of control variables are: (i) 6 survey year indicators (ii) potential experience, potential experience squared, post-graduate degree, graduate diploma; (iii) work 35+ hours per week, private/public sector, union membership; (iv) occupation (7 1-digit category dummies), industry (9 1-digit category dummies), firm size less than 10, firm size 10-50, firm size 50-200; (v) married/cohabitating, divorced/separated, number of children aged 0-4, number of children aged 5-9, number of children aged 10-14, likelihood of having (more) children; (vi) extroversion, agreeableness, conscientiousness, emotional stability, openness to experience.

Table 3: Estimates of Gender Gap in Employer Change Rates for University Graduates with $<20$ Years Experience - Random Effects Probit Models

\begin{tabular}{lccccc}
\hline & $(1)$ & $(2)$ & $(3)$ & $(4)$ & $(5)$ \\
\hline Female effect & 0.005 & 0.016 & 0.010 & 0.006 & 0.009 \\
& $(0.015)$ & $(0.015)$ & $(0.015)$ & $(0.016)$ & $(0.016)$ \\
Included control variables & & & & & $\checkmark$ \\
Year controls (6) & $\checkmark$ & $\checkmark$ & $\checkmark$ & $\checkmark$ & $\checkmark$ \\
Experience, education (4) & $\checkmark$ & $\checkmark$ & $\checkmark$ & $\checkmark$ & $\checkmark$ \\
Employment type (3) & & $\checkmark$ & $\checkmark$ & $\checkmark$ \\
Firm size, occupation, industry (19) & & & & $\checkmark$ & $\checkmark$ \\
Family status, child expectations (6) & & & & $\checkmark$ & $\checkmark$ \\
Personality (5) & -3095.5 & -3070.4 & -3042.1 & -3036.3 & -3015.3 \\
Log likelihood & 5688 & 5688 & 5688 & 5688 & 5688 \\
Sample size & & & & \\
\hline
\end{tabular}

Note: Marginal effects calculated at the mean values of the explanatory variables. Models are estimated using 24 quadrature points. ${ }^{*}$ and $* *$ denote significance at .05 and .01 levels. Sets of control variables are: (i) 6 survey year indicators (ii) potential experience, potential experience squared, post-graduate degree, graduate diploma; (iii) work 35+ hours per week, private/public sector, union membership; (iv) occupation (7 1-digit category dummies), industry (9 1-digit category dummies), firm size less than 10, firm size 10-50, firm size 50-200; (v) married/cohabitating, divorced/separated, number of children aged 0-4, number of children aged 5-9, number of children aged 10-14, likelihood of having (more) children; (vi) extroversion, agreeableness, conscientiousness, emotional stability, openness to experience. 
Table 4: Estimates of Gender Gap in Job Search, Job Applications and Job Satisfaction for University Graduates with $<20$ Years Experience

\begin{tabular}{|c|c|c|c|}
\hline Dependent Variable & Mean & $\begin{array}{l}\text { Standard } \\
\text { Deviation }\end{array}$ & $\begin{array}{c}\text { Female } \\
\text { Effect }\end{array}$ \\
\hline Searched for new job & 0.218 & 0.413 & $\begin{array}{c}-0.007 \\
(0.016)\end{array}$ \\
\hline Applied for new job & 0.456 & 0.498 & $\begin{array}{c}0.059 \\
(0.043)\end{array}$ \\
\hline Satisfaction with pay & 7.018 & 1.922 & $\begin{array}{c}-0.160 \\
(0.085)\end{array}$ \\
\hline Satisfaction with job security & 8.107 & 1.982 & $\begin{array}{c}0.104 \\
(0.086)\end{array}$ \\
\hline Satisfaction with work content & 7.460 & 1.744 & $\begin{array}{c}-0.094 \\
(0.075)\end{array}$ \\
\hline Satisfaction with hours worked & 7.092 & 1.966 & $\begin{array}{c}-0.181 * \\
(0.084)\end{array}$ \\
\hline Satisfaction with work-life balance & 7.181 & 2.258 & $\begin{array}{c}-0.188 \\
(0.100)\end{array}$ \\
\hline Overall job satisfaction & 7.442 & 1.519 & $\begin{array}{c}-0.083 \\
(0.064)\end{array}$ \\
\hline
\end{tabular}

Note: Job search and job application estimates from random effects probit models. Models are estimated using 24 quadrature points. Satisfaction estimates from linear regressions with random effects. Clustered standard errors in parentheses. ${ }^{*}$ and $* *$ denote significance at .05 and .01 levels. Models include the same set of covariates contained in model 5 in Tables 2 and 3: year dummies; experience and education; employment type; occupation, industry and firm size; family status and child expectations; and personality. Sample size in job application regression is 802. Sample size in all other regressions is 5688 . 
Table 5: The Effects of Job Changes on Wages, Job Satisfaction and Time Use for University Graduates with $<20$ Years Experience - Fixed-Effects Regression Models

\begin{tabular}{|c|c|c|c|c|}
\hline & \multicolumn{2}{|c|}{ Promotion Models } & \multicolumn{2}{|c|}{$\begin{array}{c}\text { Employer Change } \\
\text { Models }\end{array}$} \\
\hline & $\begin{array}{l}\text { Main } \\
\text { Effect }\end{array}$ & $\begin{array}{c}\text { Female } \\
\text { Interaction }\end{array}$ & $\begin{array}{l}\text { Main } \\
\text { Effect }\end{array}$ & $\begin{array}{c}\text { Female } \\
\text { Interaction }\end{array}$ \\
\hline Log Hourly Wages & $\begin{array}{l}0.083^{* *} \\
(0.014)\end{array}$ & $\begin{array}{c}-0.052^{* *} \\
(0.019)\end{array}$ & $\begin{array}{c}0.031^{*} \\
(0.013)\end{array}$ & $\begin{array}{c}-0.054^{* *} \\
(0.016)\end{array}$ \\
\hline Log Weekly Wages & $\begin{array}{l}0.094^{* *} \\
(0.015)\end{array}$ & $\begin{array}{l}-0.075^{* *} \\
(0.018)\end{array}$ & $\begin{array}{l}0.050^{* *} \\
(0.015)\end{array}$ & $\begin{array}{l}-0.071^{* *} \\
(0.019)\end{array}$ \\
\hline Satisfaction with pay & $\begin{array}{l}0.248^{* *} \\
(0.076)\end{array}$ & $\begin{array}{c}0.088 \\
(0.096)\end{array}$ & $\begin{array}{c}0.136 \\
(0.098)\end{array}$ & $\begin{array}{c}-0.011 \\
(0.115)\end{array}$ \\
\hline Satisfaction with job security & $\begin{array}{c}0.092 \\
(0.068)\end{array}$ & $\begin{array}{c}0.065 \\
(0.102)\end{array}$ & $\begin{array}{c}0.041 \\
(0.092)\end{array}$ & $\begin{array}{l}-0.005 \\
(0.115)\end{array}$ \\
\hline Satisfaction with work content & $\begin{array}{l}0.148^{* *} \\
(0.057)\end{array}$ & $\begin{array}{c}0.012 \\
(0.086)\end{array}$ & $\begin{array}{l}0.311^{* *} \\
(0.075)\end{array}$ & $\begin{array}{c}0.024 \\
(0.103)\end{array}$ \\
\hline Satisfaction with hours worked & $\begin{array}{c}0.058 \\
(0.065)\end{array}$ & $\begin{array}{c}-0.036 \\
(0.094)\end{array}$ & $\begin{array}{l}0.326^{* *} \\
(0.075)\end{array}$ & $\begin{array}{c}0.022 \\
(0.099)\end{array}$ \\
\hline Satisfaction with work-life balance & $\begin{array}{c}0.107 \\
(0.067)\end{array}$ & $\begin{array}{c}0.026 \\
(0.100)\end{array}$ & $\begin{array}{c}0.162 \\
(0.091)\end{array}$ & $\begin{array}{c}0.041 \\
(0.116)\end{array}$ \\
\hline Overall job satisfaction & $\begin{array}{l}0.148^{* *} \\
(0.050)\end{array}$ & $\begin{array}{c}-0.029 \\
(0.071)\end{array}$ & $\begin{array}{l}0.376^{* *} \\
(0.075)\end{array}$ & $\begin{array}{c}0.006 \\
(0.093)\end{array}$ \\
\hline Hours work in main job & $\begin{array}{c}0.834^{*} \\
(0.374)\end{array}$ & $\begin{array}{l}-0.413 \\
(0.515)\end{array}$ & $\begin{array}{c}0.931^{*} \\
(0.411)\end{array}$ & $\begin{array}{l}-0.794 \\
(0.562)\end{array}$ \\
\hline Hours spent on housework & $\begin{array}{l}-0.573^{* *} \\
(0.180)\end{array}$ & $\begin{array}{c}0.195 \\
(0.255)\end{array}$ & $\begin{array}{c}-0.285 \\
(0.240)\end{array}$ & $\begin{array}{c}0.430 \\
(0.270)\end{array}$ \\
\hline Hours spent on errands & $\begin{array}{l}-0.042 \\
(0.090)\end{array}$ & $\begin{array}{l}-0.010 \\
(0.141)\end{array}$ & $\begin{array}{l}-0.086 \\
(0.096)\end{array}$ & $\begin{array}{c}0.076 \\
(0.117)\end{array}$ \\
\hline Hours spent caring for relatives & $\begin{array}{l}-0.075 \\
(0.048)\end{array}$ & $\begin{array}{c}0.185 \\
(0.165)\end{array}$ & $\begin{array}{c}-0.066 \\
(0.075)\end{array}$ & $\begin{array}{c}-0.047 \\
(0.077)\end{array}$ \\
\hline Hours spent commuting to work & $\begin{array}{c}0.214 \\
(0.148)\end{array}$ & $\begin{array}{l}-0.216 \\
(0.201)\end{array}$ & $\begin{array}{c}0.093 \\
(0.154)\end{array}$ & $\begin{array}{c}0.045 \\
(0.179)\end{array}$ \\
\hline
\end{tabular}

Note: Estimates from linear regression models with individual-level fixed effects. Female interaction effect equals the coefficient on promotion*female and job-change*female variables. Clustered standard errors in parentheses. ${ }^{*}$ and $* *$ denote significance at .05 and .01 levels. Models include the same set of covariates contained in model 7 in Tables 2 and 3: year dummies; experience and education; employment type; occupation, industry and firm size; and family status and child expectations. The full-time employment status covariate is omitted from the time-use models. Sample size in all models equals 5289, which is smaller than the sample sizes used previously because of missing time-use information. 